\title{
Isolation of a protective gamma-globulin fraction interfering with the zinc sulphate turbidity test
}

\author{
B. NAGANNA, B. RAMA RAO, K. R. VENKAIAH, \\ AND P. LAKSHMANA RAO \\ From the Departments of Biochemistry and Medicine, Guntur Medical \\ College, Guntur, Andhra Pradesh, India
}

SYNOPSIS The serum of a case of hyperglobulinaemia with negative thymol and zinc sulphate turbidity reactions was studied. The serum when added to pathological sera with high turbidity values brought about a marked reduction in the original turbidity values. Also, the serum did not give the usual copper proteinate precipitate when added to copper sulphate solutions. The anomalous protein fraction responsible for the above properties was isolated from the $\gamma$ globulins by precipitation at $28 \%$ saturation with ammonium sulphate. It was found to be neither a macroglobulin (Waldenstrom's), a cryoglobulin, nor a collagen protein. Its occurrence in the very $\gamma$ globulin fraction which is responsible for many of the turbidity reactions is of great significance in the interpretation of these tests. It is suggested that the normal turbidity and flocculation reactions reported in some cases of multiple myelomatosis might be due to some such anomalous proteins.

Many of the pathological conditions associated with hyperglobulinaemia are found electrophoretically to exhibit hypergamma-globulinaemia. The abnormal turbidity and flocculation reactions observed in conditions like sarcoidosis, subacute bacterial endocarditis, rheumatoid arthritis, lymphogranuloma venereum, lupus erythematosus, etc., have been attributed to the elevated $\gamma$-globulin levels. Curiously enough, such an incidence of abnormality in the turbidity and flocculation tests is reported to be less in multiple myeloma. Blades (1951) found that in a case of multiple myeloma the thymol turbidity test was only 1 unit while the $\gamma$-globulin content was as high as 7 g. \%. Earle, Martin, and Maclagan (1951) have noted that in multiple myeloma there is a tendency towards dissociation of the various turbidity tests. In a large percentage of cases of multiple myeloma studied, Maclagan, Martin, and Lunnon (1952) found thymol turbidity and flocculation tests and serum colloidal gold tests were negative whereas ammonium sulphate and zinc sulphate turbidity tests were strongly positive. This peculiar dissociation of flocculation tests was considered to be a valuable diagnostic index of myelomatosis. Dissociation between cephalin flocculation and thymol turbidity tests has been reported in multiple myeloma by Walsh, Humoller, and Zimmerman (1955) who

Received for publication 28 June 1961. are of the opinion that a raised serum globulin level with high thymol turbidity should be interpreted as diagnostic of conditions other than multiple myeloma. It could thus be seen that though several workers have observed lack of correlation between the globulin level and the turbidity tests, no attempt seems to have been made to isolate any protein fraction which interferes with the turbidity tests in these conditions.

A case of hypergammaglobulinaemia showing negative results on thymol and zinc sulphate turbidity tests was investigated and a protective protein fraction was isolated from the $\gamma$-globulin fraction. The results are presented in this paper.

\section{EXPERIMENTAL}

The study was made of a patient, a man of 50 years, who complained of extreme weakness, loss of appetite, and constipation. He was markedly anaemic and the legs and feet were oedematous. A blood count showed: $\mathrm{Hb} 2.5 \mathrm{~g}$. $\%$, R.B.C. 1.05 m./c.mm., P.C.V. $11 \%$, reticulocytes $2 \%$, M.C.V. $104 \cdot 7$ c $\mu$., M.C.H. $23 \cdot 7 \gamma \gamma$., M.C.H.C. $22 \cdot 7 \%$, E.S.R. $35 \mathrm{~mm}$./hr., prothrombin time $20 \mathrm{sec}$., blood urea $29 \mathrm{mg}$. \%, and serum calcium $10.6 \mathrm{mg}$. \%. Gastric analysis showed achlorhydria. The urine contained traces of albumin but no Bence-Jones protein. Radiographs of the skull, chest, vertebrae, and pelvic bones showed generalized osteoporosis. Bone marrow aspiration showed a dimorphic erythropoiesis. Repeated blood transfusions 
did not improve the condition and cortisone therapy gave temporary partial relief. The patient died a few months after discharge from the hospital.

The anomalous behaviour of the serum proteins of this patient was detected during the routine determination of serum total proteins by the copper sulphate specific gravity method. When serum drops were added to the copper sulphate solutions the usual copper proteinate envelope around the drop was not observed. Instead, the serum drop maintained its translucence as it descended and mixed with the copper sulphate solutions without leaving any precipitate. The protein content determined by the biuret method of Wolfson, Cohn, Calvary, and Ichiba (1948) was found to be $10.5 \mathrm{~g} . / 100 \mathrm{ml}$. serum. Paper electrophoretic analysis gave the following results:-Albumin 2.35 g. $\%, \alpha_{1}$ globulin 1.1 g. $\%$, $\alpha_{2}$ globulin $0.8 \mathrm{~g} . \%, \beta$ globulin 0.75 g. $\%$, and $\gamma$ globulin $5.5 \mathrm{~g} . \%$.

The peculiar behaviour of this serum towards copper sulphate solutions prompted us to study the zinc sulphate and thymol turbidity reactions. Both the tests were found to be negative. This abnormal behaviour, particularly towards the zinc sulphate turbidity test, must be due either to an atypical $\gamma$ globulin or to the presence of an excessive amount of protective proteins which are probably confined to the albumin fraction. Sera of typical cases of infective hepatitis with high zinc sulphate turbidity values were mixed with the experimental serum in different proportions and it was found that the zinc sulphate turbidity values of these mixtures were markedly reduced. It is therefore concluded that the patient's serum contained a protective protein fraction.

In order to evaluate whether the $\gamma$ globulin of the patient's serum was normal it was precipitated by ammonium sulphate (Wolfson et al., 1948), dissolved in water and dialysed at $10^{\circ} \mathrm{C}$. till free from ammonium sulphate. The zinc sulphate turbidity value of this fraction was found to be zero. Also, when this fraction was mixed with serum from a patient with infective hepatitis, the original zinc sulphate turbidity value of the latter was markedly decreased. It was surprising that the $\gamma$ globulins, considered to be responsible for high turbidity reactions, should be found to possess such absolutely contrary properties.

The $\gamma$ globulins were therefore subjected to subfractionation with ammonium sulphate in order to assess whether this protective property could be ascribed to a subfraction or whether it was shared by the entire $\gamma$ globulin. Globulins, other than the $\gamma$ globulins, as well as the albumin fractions, were tested after isolation by precipitation with ammonium sulphate followed by dialysis, and it was found that they did not possess any protective property.

Aliquots, each of $2 \mathrm{ml}$., of the patient's serum cooled in ice were fractionated with ice-cold saturated ammonium sulphate (adjusted to $p \mathrm{H} \mathrm{7.0)}$ into three fractions; fraction I was precipitated at $28 \%$ saturation with ammonium sulphate, fraction II between $28 \%$ and $29.5 \%$ saturation, fraction III between $29.5 \%$ and $34 \%$ saturation. Fraction I, unlike the other two, appeared translucent, and was so sticky that it could be removed with a glass rod. The fractions were dissolved in the minimum amounts of water, dialysed at $10^{\circ} \mathrm{C}$. till free
from ammonium sulphate, and the volumes brought to experimental serum, were mixed with $0.05 \mathrm{ml}$. aliquots of $\stackrel{\oplus}{+}$ infective hepatitis serum, diluted to $9.0 \mathrm{ml}$. with zinc? sulphate buffer, and the turbidities were measured in a 을 Lumitron photoelectric colorimeter at $650 \mathrm{~m} \mu$. Floccu- $\frac{}{7}$

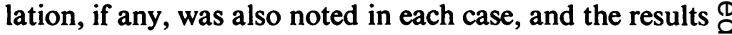
are given in the table.

\section{DISCUSSION}

It is obvious from the table that the protective $\overrightarrow{\vec{\omega}}$ property of the experimental serum is confined to a fraction of the $\gamma$ globulin, and this fraction, being the earliest to be precipitated with ammonium sul- $\vec{G}$ phate, is probably a globulin with a high molecular weight. As there was no precipitate at $25 \%$ saturation $\omega$ this protein fraction probably has a molecular weight 0 less than that of the fibrinogen. The abnormal protein cannot be the macroglobulin of Walden- $\vec{c}$ ström as it did not show any euglobulin reaction. As no reversible cold-insoluble protein could be demonstrated this anomalous protein could not be $₹$ a cryoglobulin. Hydroxyproline, an amino-acid $\vec{\bullet}$ present in collagen and not found in normal blood $\stackrel{N}{N}$ proteins, was reported to be present in a cryo- 0 globulin by Mandema, van der Schaaf, and Huisman (1955). The gelatinous nature of fraction $I$ led us to investigate whether it contained any hydroxyproline. Quantitative measurement by the $\frac{0}{D}$ method of Leach (1960) showed no trace of hydroxyproline in fraction I. The anomalous protein is therefore not a macroglobulin, a cryoglobulin, nor a collagenous protein.

The results of this study reveal the existence of anomalous proteins in certain pathological conditions, which, by functioning as protective colloids, $\dot{-}$ interfere with one or more of the turbidity and flocculation reactions. This finding becomes very $\delta$ significant when it is realized that these anomalous 3 proteins could be associated with the very $\gamma$ globulins 을 that are said to be responsible for many of the

\section{TABLE}

PROPERTIES OF DIFFERENT PROTEIN FRACTIONS AND OF O

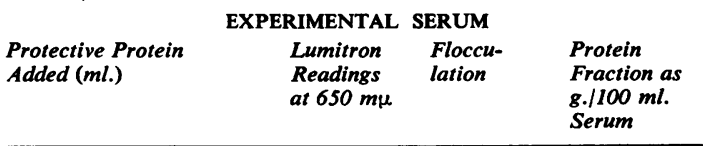

0.5 fraction $I$

0.4 fraction $I$

$0 \cdot 3$ fraction I

$0 \cdot 2$ fraction $I$

0.5 fraction II

0.5 fraction III

0.05 experimental serum

0.1 experimental serum

0.15 experimental serum

None 
flocculation reactions. The enigmatic turbidity results reported by Blades (1951), Maclagan et al. (1952), and Walsh et al. (1955) with multiple myelomatosis sera may be due to some protective protein of the type described here. It is suggested that whenever a dissociation of the turbidity (and flocculation) reactions occurs with an associated hyperglobulinaemia or other dysproteinaemia, attempts should be made to isolate and characterize the anomalous protective protein. Sera from two cases of proved multiple myelomatosis have been investigated on similar lines and found to exert a similar protective effect in turbidity tests. They differed, however, in that they did form copper proteinate precipitates when added to copper sulphate.
We wish to thank Dr. D. Jagannatha Reddy, Principal and Professor of Pathology, Guntur Medical College, for helpful discussions.

\section{REFERENCES}

Blades, A. N. (1951). Brit. med. J., 1, 169.

Earle, J. H. O., Martin, N. H., and Maclagan, N. F. (1951). J. clin. Path., 4, 117.

Leach, A. A. (1960). Biochem. J., 74, 70.

Maclagan, N. F., Martin, N. H., and Lunnon, J. B. (1952). J. clin. Path., 5, 1.

Mandema, E., Schaaf, P. C. van der, and Huisman, T. H. J. (1955). J. Lab. clin. Med., 45, 261.

Walsh, J. R., Humoller, F. L., and Zimmerman, H. J. (1955). J. Lab. clin. Med., 45, 253.

Wolfson, W. Q., Cohn, C., Calvary, E., and Ichiba, F. (1948). Amer. J. clin. Path., 18, 723. 